\title{
Pengaruh Kecerdasan Emosional, Kecerdasan Intelektual, Kecerdasan Spiritual dan Kecerdasan Sosial Terhadap Pemahaman Akuntansi
}

\author{
Hairul Anam ${ }^{1)}$; Lia Ardillah ${ }^{2)}$ \\ Fakultas Ekonomi Universitas Balikpapan \\ Jl. Pupuk Raya Balikpapan; Telp./Fax. 0542-764205 \\ E-mail: hrlbpn@gmail.com
}

\begin{abstract}
The role of educational institutions is essential to produce accounting graduates who qualified to compete in the world of work, to produce quality accounting graduates college party must know what are the factors that affect a student receives a lesson in understanding the factors that can support accounting course success is not intelligence, but also with intelligent personality. The aim of the study was to determine the Influence of emotional intelligence, intellectual, spiritual intelligence, and social intelligence to the understanding of accounting either partially or simultaneously. The study was conducted on students studying accounting in college at the University of Balikpapan Balikpapan City. The author examines accounting students who are nearing the end of the semester, because at that level the student is considered to have the full benefit on teaching accounting courses given. The results showed that the partial intelligence and emotional intelligence significantly influence the understanding of accounting whereas spiritual intelligence and social intelligence has no Influence on the understanding of accounting. While simultaneously emotional intelligence, intellectual, spiritual intelligence and social intelligence significantly influence accounting understanding.
\end{abstract}

Key words: Emotional Intelligence, Intellectual Intelligence, Spiritual Intelligence, Social Intelligence, Understanding Accounting.

\begin{abstract}
Abstrak
Peran lembaga pendidikan sangat penting untuk menghasilkan lulusan sarjana akuntansi yang berkualitas agar dapat bersaing dalam dunia kerja, untuk menghasilkan lulusan sarjana akuntansi yang berkualitas pihak perguruan tinggi harus mengetahui apa saja faktor-faktor yang mempengaruhi seorang mahasiswa dalam memahami pelajaran yang diterimanya, faktor yang dapat mendukung keberhasilan program studi akuntansi adalah bukan kecerdasan otak saja tetapi juga dengan memiliki kecerdasan kepribadian. Tujuan dari penelitian adalah untuk mengetahui pengaruh kecerdasan emosional, kecerdasan intelektual, kecerdasan spiritual, dan kecerdasan sosial terhadap pemahaman akuntansi baik secara parsial maupun simultan. Penelitian ini menggunakan sampel mahasiswa akuntansi yang telah mendekati semester akhir, dianggap telah mendapatkan manfaat penuh atas mata kuliah pengajaran akuntansi yang diberikan. Hasil penelitian secara parsial kecerdasan emosional dan kecerdasan intelektual berpengaruh secara signifikan terhadap pemahaman akuntansi sedangkan kecerdasan spiritual dan kecerdasan sosial tidak berpengaruh terhadap pemahaman akuntansi. Sedangkan secara simultan kecerdasan emosional, kecerdasan intelektual, kecerdasan spiritual dan kecerdasan sosial berpengaruh secara signifikan terhadap pemahaman akuntansi.
\end{abstract}

Kata Kunci: Kecerdasan Emosional, Kecerdasan Intelektual, Kecerdasan Spiritual, Kecerdasan Sosial, Pemahaman Akuntansi.

\section{Pendahuluan}

\subsection{Latar Belakang Masalah}

Untuk menghasilkan lulusan sarjana akuntansi yang berkualitas pihak perguruan tinggi harus mengetahui apa saja faktor-faktor yang mempengaruhi seorang mahasiswa dalam memahami pelajaran yang diterimanya, Kebanyakan program pendidikan hanya berpusat pada kecerdasan

intelektual saja padahal harus juga diimbangi dengan kecerdasan kepribadiannya seperti diimbangi bagaimana mengembangkan kecerdasan hati dengan ketangguhan, inisiatif, kejujuran, dan kemampuan beradaptasi. Banyak contoh disekitar kita membuktikan bahwa orang yang 
memiliki kecerdasan otak saja, atau banyak memiliki gelar yang tinggi belum tentu sukses bekiprah didunia pekerjaan. Bahkan seringkali yang kecerdasan intelektual lebih rendah ternyata banyak yang lebih berhasil karena mereka memiliki kecerdasan kepribadian. Kecerdasan emosional mahasiswa memiliki perngaruh terhadap prestasi belajar mahasiswa. Kecerdasan emosional ini mampu melatih kemampuan mahasiswa untuk mengelola perasaannya, untuk memotivasi dirinya sendiri, kesanggupan untuk tegar dalam menghadapi frustasi, kesanggupan mengendalikan dorongan dan menunda kepuasan sesaat, mengatur suasana hati yang relatif, serta mampu berempati dan bekerjasama dengan orang lain. Kecerdasan ini dapat mendukung seorang mahasiswa dalam mencapai tujuan dan cita-citanya.

Dalam memahami akuntansi adanya kecerdasan intelektual merupakan hal yang penting juga untuk dipertimbangkan. Mahasiswa akuntansi yang memiliki kecerdasan intelektual yang baik tentu memiliki pemahaman akuntansi yang baik pula karena kecerdasan intelektual yaitu cerdas dalam berfikir serta cepat tanggap dalam memperoleh suatu ilmu atau pelajaran yang telah diberikan. Mahasiswa akuntansi yang cerdas spiritualnya pada saat masih duduk dibangku kuliah akan mampu membantu melatih dalam pemecahan permasalahan-permasalahan yang akan datang seperti disaat sudah mendapatkan title kesarjanaan lalu bekerja di suatu perusahaan, untuk dapat sukses berkiprah didunia pekerjaan dibutuhkan juga kecerdasan spiritual karena dengan memiliki kecerdasan tersebut berarti telah memiliki sifat jujur, bertanggung jawab dan bermoral yang akan diterapkan dalam pekerjaannya. Sifat yang demikian sangat penting dan dibutuhkan didunia pekerjaan agar menjadi seseorang yang sukses dan dapat dipercaya.

\subsection{Rumusan Masalah}

Penelitian ini bertujuan untuk mengetahui apakah kecerdasan emosional, kecerdasan intelektual, kecerdasan spiritual, dan kecerdasan sosial berpengaruh terhadap pemahaman akuntansi?

\section{Kerangka Teoritis dan Pengembangan Hipotesis \\ 2.1 Pengertian Kecerdasan}

Anita E. Woolfolk dalam Sunar (2010), Mengemukakan bahwa menurut teori lama kecerdasan meliputi tiga pengertian yaitu kemampuan untuk belajar, keseluruhan pengetahuan yang diperoleh, dan kemampuan untuk beradaptasi dengan situasi baru atau lingkungan pada umumnya. Chaplin dalam Sunar (2010), Memberikan pengertian kecerdasan sebagai kemampuan menghadapi dan menyesuaikan diri terhadap situasi baru secara cepat dan efektif.

\subsection{Kecerdasan Emosional}

Kemampuan

mengembangkan kepribadian mahasiswa pada masa sekarang ini lebih dikenal dengan istilah Emotional Quotient (EQ) atau Kecerdasan Emosional. Goleman (2000), Kecerdasan Emosional adalah kemampuan seperti kemampuan untuk memotivasi diri sendiri dan bertahan menghadapi frustasi, mengendalikan dorongan hati dan tidak melebihlebihkan kesenangan, mengatur suasana hati dan menjaga agar beban stres tidak melumpuhkan kemampuan berfikir, berempati dan berdoa. Sunar (2010), Kecerdasan emosional atau biasa dikenal dengan EQ (Emotional quotient) adalah kecerdasan kemampuan seseorang untuk 
menerima, menilai, mengelola, serta mengontrol emosi dirinya dan orang lain disekitarnya. Salovey dan Mayer dalam Jamaluddin dan Rahayu Indriasari (2011), kecerdasan emosional adalah kemampuan mengetahui perasaan sendiri dan perasaan orang lain, serta menggunakan perasaan tersebut menuntun pikiran perilaku seseorang.

\subsection{Kecerdasan Intelektual}

Dalam memahami akuntansi adanya kecerdasan intelektual merupakan hal yang penting juga untuk dipertimbangkan. Sunar (2010), Kecerdasan Intelektual (IQ) merupakan kemampuan untuk memecahkan masalah secara logis dan akademis. David Wechsler dalam Tikollah, dkk (2006), kecerdasan intelektual sebagai totalitas kemampuan seseorang untuk bertindak dengan tujuan tertentu, berpikir secara rasional, serta menghadapi lingkungannya dengan efektif.

Azwar dalam Tikollah, dkk (2006), kecerdasan intelektual merupakan interprestasi hasil tes inteligensi (kecerdasan) ke dalam angka yang dapat menjadi petunjuk mengenai kedudukan tingkat inteligensi seseorang.

\subsection{Kecerdasan Spiritual}

\section{Kecerdasan}

Spiritual ditemukan oleh Danah Zohar dan Ian Marshall pada pertengahan tahun 2000. Danah Zohar dan Ian Marshall dalam Agustian (2002), Mendefinisikan kecerdasan spritual adalah kecerdasan untuk menghadapi persoalan makna atau value, yaitu kecerdasan untuk menempatkan prilaku dan hidup kita dalam konteks makna yang lebih luas dan kaya, kecerdasan untuk menilai bahwa tindakan atau jalan hidup seseorang lebih bermakna dibandingkan dengan yang lain.

2.5 Hubungan Kecerdasan Emosional, Kecerdasan Intelektual, Kecerdasan Spiritual Dan Kecerdasan Sosial Terhadap Pemahaman Akuntansi

Goleman (2000), Kecerdasan Emosional adalah kemampuan seperti kemampuan untuk memotivasi diri sendiri dan bertahan menghadapi frustasi, mengendalikan dorongan hati dan tidak melebih-lebihkan kesenangan, mengatur suasana hati dan menjaga agar beban stres tidak melumpuhkan kemampuan berfikir, berempati dan berdoa. Kecerdasan emosional yang baik dapat dilihat dari kemampuan mengenal diri sendiri, mengendalikan diri, memotivasi diri, berempati, dan kemampuan sosial.

Sunar (2010) kecerdasan Intelektual merupakan kemampuan untuk memecahkan masalah secara logis dan akademis. Seorang mahasiswa akuntansi yang memilki kecerdasan intelektual yang baik maka akan cepat mampu memahami akuntansi dan dapat membaca dengan penuh pemahaman serta akan selalu menunjukkan keingintahuannya terhadap akuntansi.

Kecerdasan Spiritual, Danah Zohar dan Ian Marshall dalam Agustian (2002) adalah kecerdasan untuk menghadapi persoalan makna atau value, yaitu kecerdasan untuk menempatkan prilaku dan hidup kita dalam konteks makna yang lebih luas dan kaya, kecerdasan untuk menilai bahwa tindakan atau jalan hidup seseorang lebih bermakna dibandingkan dengan yang lain.

Kecerdasan Sosial, Thorndike dalam Sunar (2010) adalah kemampuan untuk memahami dan mengelola hubungan manusia. Kecerdasan sosial berarti orang yang mampu membuat orang-orang yang berada disekitarnya merasa nyaman dan santai dengan keberadaan dirinya. 


\subsection{Hipotesis Penelitian}

Sehubungan

dengan

permasalahan diatas, maka diajukan hipotesis sebagai berikut:

$\begin{array}{llr}\mathrm{H}_{1}: & \begin{array}{l}\text { Kecerdasan } \\ \text { berpengaruh }\end{array} & \begin{array}{r}\text { emosional } \\ \text { terhadap }\end{array} \\ \mathrm{H}_{2}: & \begin{array}{l}\text { pemahaman akuntansi. } \\ \text { Kecerdasan } \\ \text { berpengaruh }\end{array} & \text { intelektual } \\ & \text { pemahaman akuntansi. } \\ \mathrm{H}_{3}: & \begin{array}{ll}\text { Kecerdasan } \\ \text { berpengaruh }\end{array} & \text { spiritual } \\ & \text { pemahaman akuntasi. }\end{array}$

$\mathrm{H}_{4}$ : Kecerdasan sosial berpengaruh terhadap pemahaman akuntansi.

\section{Metode Penelitian}

\subsection{Rancangan Penelitian}

Penelitian ini dilakukan secara kuantitatif yaitu penelitian yang digunakan untuk meneliti pada populasi/sampel tertentu dan pengumpulan data menggunakan instrumen penelitian, dengan desain riset deskriptif. Desain deskriptif bertujuan untuk menjelaskan, seperti mengetahui berapa besar hubungan suatu variabel.

\subsection{Teknik Pengambilan Sampel}

dapat $\begin{gathered}\text { Penentuan jumlah sampel } \\ \text { dilakukan dengan cara }\end{gathered}$ perhitungan statistik yaitu dengan menggunakan Rumus Slovin. Kriyantono dalam Jamaluddin (2011), Rumus Slovin digunakan untuk menentukan ukuran sampel dari populasi yang telah diketahui jumlahnya yaitu sebanyak 248 orang. Untuk tingkat presisi yang ditetapkan dalam penentuan sampel adalah $10 \%$. Alasan peneliti menggunakan tingkat presisi $10 \%$ karena jumlah populasi kurang dari 1000.

\subsection{Data dan Metode Pengumpulan Data}

Metode ini dilakukan dengan mendatangi responden, memberikan atau menyebarkan daftar pertanyaan kepada responden yaitu mahasiswa akuntansi satu per satu, melihat apakah calon memenuhi persyaratan sebagai calon responden, lalu menanyakan kesediaannya untuk mengisi kuesioner. Daftar pertanyaan yang digunakan adalah pertanyaan terstuktur dan responden cukup memberi tanda $(\sqrt{ })$ pada jawaban yang dipilih, kemudian responden langsung mengembalikan daftar pertanyaan setelah diisi.

Dalam penelitian ini responden yang dijadikan sampel penelitian adalah mahasiswa prodi akuntansi angkatan 2010 dan 2011. Metode pengumpulan data yang digunakan dalam penelitian ini menggunakan data primer.

\subsection{Data Responden}

Berdasarkan data yang diperoleh dari 75 responden mengenai distribusi frekuensi identitas responden berdasarkan jenis kelamin, usia, angkatan dan IPK secara berturutturut.

3.4.1.Data responden berdasarkan jenis kelamin dapat dilihat bahwa mayoritas responden berjenis kelamin perempuan yaitu sebanyak 63 orang atau $84 \%$ dan sisanya berjenis kelamin laki-laki yaitu sebanyak 12 orang atau $16 \%$.

3.4.2 Data responden berdasarkan usia dapat dilihat bahwa 4 atau $5 \%$ responden dari 75 sampel penelitian berusia $<21$ tahun, 65 atau $87 \%$ responden dari 75 sampel penelitian ini berusia 21 - 25 tahun, 6 atau $8 \%$ responden dari 75 sampel penelitian ini berusia 26 - 30 tahun, dan tidak ada responden yang berusia > 30 tahun.

3.4.3. Data responden berdasarkan angkatan menunjukkan bahwa angkatan responden tahun 2010 sebanyak 37 orang atau $49 \%$ dari 75 sampel penelitian ini dan 
angkatan tahun 2011 sebanyak 38 orang atau $51 \%$ dari 75 sampel penelitian ini.

3.4.4. Data responden berdasarkan IPK diperoleh bahwa 1 atau $1 \%$ responden dari 75 sampel penelitian ini mahasiswa dengan IPK $<2,6,24$ atau $32 \%$ responden dari 75 sampel penelitian ini mahasiswa dengan IPK 2,6 - 3,0, 46 atau $62 \%$ responden dari 75 sampel penelitian ini mahasiswa dengan IPK 3,1 -3,5, dan 4 atau $5 \%$ responden dari 75 sampel penelitian ini mahasiswa dengan IPK >3,5.

\section{Analisis dan Pembahasan.}

\subsection{Analisis Data}

\subsubsection{Analisis Deskriptif}

Pada variabel pertama yaitu variabel kecerdasan emosional memiliki nilai minimum sebesar 2,110, nilai maksimum sebesar 4,790, rata-rata 3,82053, dan standar deviasi sebesar 423511. Pada variabel kedua yaitu kecerdasan intelektual, memiliki nilai minimum sebesar 2,200, nilai maksimum sebesar 4,900, rata-rata 3,54267, dan standar deviasi sebesar 484956. Pada variabel ketiga yaitu kecerdasan spiritual, memiliki nilai minimum sebesar 2,940, nilai maksimum sebesar 4,880, rata-rata 3,84693, dan standar deviasi sebesar 446687. Dan pada variabel keempat yaitu kecerdasan sosial memiliki nilai minimum sebesar 2,570, nilai maksimum sebesar 5,000, rata-rata 3,64360, dan standar deviasi sebesar 605427.

\subsubsection{Koefisien Determinasi}

Berdasarkan hasil perhitungan diketahui bahwa nilai $R$ Square yang diperoleh sebesar 0,306 atau 30,6\% Sedangkan nilai Adjusted $R$ Square yang diperoleh adalah sebesar 0,267 atau $26,7 \%$.
Karena dalam penelitian ini digunakan empat variabel bebas maka koefisien determinasi yang digunakan adalah angka dari nilai Adjust $R$ Square sebesar 26,7 \%. Angka tersebut memberikan bukti bahwa pemahaman akuntansi dipengaruhi oleh tingkat kecerdasan emosional, kecerdasan intelektual, kecerdasan spiritual, dan kecerdasan sosial sebesar 26,7 \% sedangkan sisanya sebesar 73,3 \% dipengaruhi oleh variabel lain diluar penelitian ini.

\subsubsection{Pengujian Hipotesis}

\section{Uji $F$}

Hipotesis pengaruh variabel bebas secara bersama-sama terhadap variabel terikatnya dilakukan dengan menggunakan uji F. Hasil perhitungan statistik menunjukkan nilai $F_{\text {hitung }}=$ 7,723 dengan signifikansi sebesar 0,000 $<0,05$. Hal ini berarti bahwa secara bersama-sama kecerdasan emosional, kecerdasan intelektual, kecerdasan spiritual, dan kecerdasan sosial mempunyai pengaruh yang signifikan terhadap pemahaman akuntansi sehingga hipotesis diterima.

2. Uji t

Uji $\mathrm{t}$ dimaksudkan untuk mengetahui seberapa jauh pengaruh satu variabel independen (kecerdasan emosional, kecerdasan intelektual, kecerdasan spiritual, dan kecerdasan sosial) secara individual dalam menerangkan variabel dependen (pemahaman akuntansi).

1) Variabel Kecerdasan Emosional terhadap pemahaman akuntansi

Bahwa nilai koefisien regresi kecerdasan emosional memiliki tingkat signifikansi 0,000 nilai ini lebih kecil dari 0,05 atau nilai signifikan $\operatorname{Sig}<\alpha$. Selain itu diperoleh nilai t hitung 4,126 $>$ dari $t$ tabel. Ini berarti hipotesis penelitian yang menyatakan kecerdasan emosional memiliki pengaruh yang signifikan terhadap pemahaman akuntansi diterima. 
2) Variabel Kecerdasan Intelektual terhadap pemahaman akuntansi

Bahwa nilai koefisien regresi kecerdasan intelektual memiliki tingkat signifikansi 0,015 nilai ini lebih kecil dari 0,05 atau nilai signifikan $\operatorname{Sig}<\alpha$. Selain itu diperoleh nilai t hitung 2,495 $>$ dari $\mathrm{t}$ tabel. Ini berarti hipotesis penelitian yang menyatakan kecerdasan intelektual memiliki pengaruh yang signifikan terhadap pemahaman akuntansi diterima.

3) Variabel Kecerdasan Spiritual terhadap pemahaman akuntansi

Bahwa nilai koefisien regresi kecerdasan spiritual memiliki tingkat signifikansi 0,546 nilai ini lebih besar dari 0,05 atau nilai signifikan $\mathrm{Sig}>\alpha$. Selain itu diperoleh nilai t hitung $606<$ dari $\mathrm{t}$ tabel. Ini berarti hipotesis penelitian yang menyatakan kecerdasan spiritual memiliki pengaruh yang signifikan terhadap pemahaman akuntansi ditolak.

4) Variabel Kecerdasan Sosial terhadap pemahaman akuntansi

Bahwa nilai koefisien regresi kecerdasan sosial memiliki tingkat signifikansi 0,674 nilai ini lebih besar dari 0,05 atau nilai signifikan $\mathrm{Sig}>\alpha$. Selain itu diperoleh nilai t hitung $422<$ dari $\mathrm{t}$ tabel. Ini berarti hipotesis penelitian yang menyatakan kecerdasan sosial memiliki pengaruh yang signifikan terhadap pemahaman akuntansi ditolak.

\subsection{Pembahasan}

Berdasarkan analisis secara simultan atau keseluruhan pengujian yang telah dilakukan diperoleh hasil nilai signifikansi $0,000<0,05$ yang berarti menunjukkan bahwa kecerdasan emosional, kecerdasan intelektual, kecerdasan spiritual, dan kecerdasan sosial bersama-sama berpengaruh secara signifikan terhadap pemahaman akuntansi. Hasil penelitian ini sama dengan penelitian yang dilakukan oleh Heringsih, dkk (2005), Tikollah, dkk
(2006), Jamaluddin dan Rahayu Indriasari (2011), dan Wiyono (2012).

1. Hasil Uji Kecerdasan Emosional $\left(\mathrm{X}_{1}\right)$ Terhadap Pemahaman Akuntansi (Y).

Berdasarkan uji parsial yang telah dilakukan antara kecerdasan emosional $\left(\mathrm{X}_{1}\right)$ terhadap pemahaman akuntansi $(\mathrm{Y})$ menunjukkan bahwa kecerdasan emosional memiliki tingkat signifikan $0,000<0,05$, karena tingkat signifikansi lebih kecil dari pada 0,05 maka hal ini membuktikan bahwa kecerdasan emosional memiliki pengaruh yang signifikan terhadap pemahaman akuntansi. Hasil penelitian ini sama dengan penelitian yang dilakukan oleh Heringsih, dkk (2005), Jamaluddin dan Rahayu Indriasari (2011), Wiyono (2012) yang menyatakan kecerdasan emosional berpengaruh signifikan terhadap pemahaman akuntansi tetapi berbeda dengan hasil penelitian Tikollah, dkk (2006), dan Fahrianta, dkk (2012) yang menyatakan kecerdasan emosional tidak berpengaruh signifikan terhadap pemahaman akuntansi. Semakin tinggi kecerdasan emosional mahasiswa tersebut, semakin tinggi pula tingkat pemahaman akuntansinya. Kecerdasan emosional berpengaruh terhadap pemahaman akuntansi dikarenakan seorang mahasiswa tersebut memiliki motivasi untuk selalu giat belajar sehingga akan memahami pelajaran yang di ajarkan.

2. Hasil Uji Kecerdasan Intelektual $\left(\mathrm{X}_{2}\right)$ Terhadap Pemahaman Akuntansi (Y).

Berdasarkan uji parsial yang telah dilakukan antara kecerdasan Intelektual $\left(\mathrm{X}_{2}\right)$ terhadap pemahaman akuntansi $(\mathrm{Y})$ menunjukkan bahwa kecerdasan Intelektual memiliki tingkat signifikan $0,015<0,05$, karena tingkat signifikansi lebih kecil dari pada 0,05 maka hal ini membuktikan bahwa kecerdasan intelektual memiliki pengaruh yang signifikan terhadap pemahaman akuntansi. Hasil penelitian ini sama dengan penelitian yang dilakukan oleh 
Tikollah, dkk (2006), Jamaluddin dan Rahayu Indriasari (2011) yang menyatakan kecerdasan intelektual berpengaruh signifikan terhadap pemahaman akuntansi. Semakin tinggi kecerdasan intelektual mahasiswa tersebut, semakin tinggi pula tingkat pemahaman akuntansinya. Kecerdasan Intelektual berpengaruh terhadap pemahaman akuntansi dikarenakan seorang mahasiswa tersebut memiliki kemampuan untuk memecahkan masalah dan cepat tanggap dalam menerima pengajaran yang di berikan sehingga akan mampu memahami pengajaran akuntansi.

3. Hasil Uji Kecerdasan Spiritual $\left(\mathrm{X}_{3}\right)$ Terhadap Pemahaman Akuntansi (Y).

Berdasarkan uji parsial yang telah dilakukan antara kecerdasan Spiritual $\left(\mathrm{X}_{3}\right)$ terhadap pemahaman akuntansi $(\mathrm{Y})$ menunjukkan bahwa kecerdasan Spiritual memiliki tingkat signifikan $0,546>0,05$, karena tingkat signifikansi lebih besar dari pada 0,05 maka hal ini membuktikan bahwa kecerdasan spiritual tidak memiliki pengaruh yang signifikan terhadap pemahaman akuntansi. Hasil penelitian ini sama dengan penelitian yang dilakukan oleh Tikollah, dkk (2006) yang menyatakan bahwa kecerdasan spiritual tidak berpengaruh terhadap pemahaman akuntansi tetapi berbeda dengan hasil penelitian Jamaluddin dan Rahayu Indriasari (2011) dan Fahrianta, dkk (2012) yang menyatakan bahwa kecerdasan spiritual berpengaruh signifikan terhadap pemahaman akuntansi. Kecerdasan spiritual tidak berpengaruh terhadap pemahaman akuntansi karena seorang mahasiswa tersebut kurang memiliki kemampuan untuk memberi arti dan nilai disetiap perbuatan yang dilakukannya contohnya seperti mencontek sehingga tidak mempengaruhi akuntansinya.

4. Hasil Uji Kecerdasan Sosial $\left(\mathrm{X}_{4}\right)$ Terhadap Pemahaman Akuntansi (Y).
Berdasarkan uji parsial yang telah dilakukan antara kecerdasan Sosial $\left(\mathrm{X}_{4}\right)$ terhadap pemahaman akuntansi (Y) menunjukkan bahwa kecerdasan Sosial memiliki tingkat signifikan $0,674>0,05$, karena tingkat signifikansi lebih besar dari pada 0,05 maka hal ini membuktikan bahwa kecerdasan sosial tidak memiliki pengaruh yang signifikan terhadap pemahaman akuntansi. Kecerdasan sosial tidak berpengaruh terhadap pemahaman akuntansi karena seorang mahasiswa tersebut dalam bergaul atau bersosialisasi dan berkumpul hanya lebih mementingkan memperbanyak teman dan membahas hal-hal yang menyangkut diluar mata kuliah akuntansi contohnya seperti bergosip sehingga tidak mempengaruhi pemahaman akuntansinya.

\section{Kesimpulan}

Berdasarkan hasil dari penelitian mengenai pengaruh kecerdasan emosional, kecerdasan intelektual, kecerdasan spiritual dan kecerdasan sosial terhadap pemahaman akuntansi, dapat diambil kesimpulan bahwa:

1. Berdasarkan pengujian determinasi dibuktikan bahwa pengaruh kecerdasan emosional, kecerdasan intelektual, kecerdasan spiritual, dan kecerdasan sosial terhadap pemahaman akuntansi sebesar dua puluh enam koma tujuh persen sedangkan sisanya dipengaruhi faktor lain diluar penelitian ini.

2. Secara parsial variabel kecerdasan emosional dan kecerdasan intelektual memiliki pengaruh yang signifikan terhadap pemahaman akuntansi. Sedangkan variabel kecerdasan spiritual dan kecerdasan sosial tidak memiliki pengaruh yang signifikan terhadap pemahaman akuntansi. 
3. Secara simultan variabel kecerdasan emosional, kecerdasan intelektual, kecerdasan spiritual, dan kecerdasan sosial memiliki pengaruh yang signifikan terhadap pemahaman akuntansi.

\section{Daftar Pustaka}

Agustian, Ary Ginanjar, 2002, Rahasia Sukses Membangun Kecerdasan Emosi dan Spiritual, Cetakan Ketujuh, Penerbit Arga, Jakarta

Fahrianta, Riswan Yudhi, Akhmad Yafiz Syam, Saifhul Anuar Syahdan, 2012, "Pengaruh Kecerdasan Emosional dan Kecerdasan Spiritual Mahasiswa Akuntansi Terhadap Tingkat Pemahaman Akuntansi", Jurnal Socioscientia Kopertis Wilayah XI Kalimantan, Vol. 4, No. 2

Goleman, Daniel, 2000, Emotional Intelligence, Cetakan Kesepuluh, Penerbit PT Gramedia Pustaka Utama, Jakarta , 2007, Social Intellegence, Cetakan Kesepuluh, Penerbit PT Gramedia Pustaka Utama, Jakarta

Heriningsih, Sucahyo, Sri Suryaningsum, Windyastuti, 2005, "Pengaruh Kecerdasan Emosional Pada Pemahaman Pengetahuan Akuntansi Di Tingkat Pengantar Dengan Penalaran Dan Pendekatan Sistem", Jurnal Akuntansi dan Manajemen, Vol. XVI, No.2

Ikhsan, Irfan, Muhammad Ishak, 2005, Akuntansi Keperilakuan, Cetakan Pertama, Penerbit Salemba Empat, Jakarta

Jamaluddin, Rahayu Indrisari, 2011, "Pengaruh Kecerdasan Intelektual,
Kecerdasan Emosional dan Kecerdasan Spiritual Terhadap Etika Mahasiswa Akuntansi Fakultas Ekonomi Universitas Tadulako", Jurnal Pamator, Vol.4, No.1

Jusup, Al Haryono, 2005, Dasar-dasar Akuntansi, Edisi 6, Cetakan Kelima, Bagian Penerbit Sekolah Tinggi Ilmu Ekonomi TKPN, Yogyakarta

Priyatno, Duwi, 2013, Mandiri Belajar Analisis Data dengan SPSS, Cetakan Pertama, Penerbit Mediakom, Yogyakarta

Sukidi, 2002, Rahasia Sukses Hidup Bahagia Kecerdasan Spiritual, Cetakan Pertama, Penerbit PT Gramedia Pustaka Utama, Jakarta

Sunar, Dwi, 2010, Edisi Lengkap Tes IQ, $E Q$, dan $S Q$, Cetakan Pertama, Penerbit Flash Books, Jogjakarta

Tikollah, M.Ridwan, Iwan Triyuwono, H. Unti Ludigdo, 2006, "Pengaruh Kecerdasan Intelektual, Kecerdasan Emosional dan Kecerdasan Spiritual Terhadap Sikap Etis Mahasiswa Akuntansi", Jurnal SNAIX, Padang, 23-26 Agustus

Wibowo, Agung Edy, 2012, Aplikasi Praktis SPSS Dalam Penelitian, Cetakan Pertama, Penerbit Gava Media, Yogyakarta

Wiyono, M Wimbo, 2012, "Pengaruh Kecerdasan Emosional Terhadap Tingkat Pemahaman Akuntansi", Jurnal WIGA, Vol.2, No.2 